\title{
Evaluation of Nigella sativa and honey combination for treatment of kidney stone: a randomized, placebo controlled clinical trial
}

\author{
Laleh Zaheri Abdehvand, ${ }^{\mathrm{a}}$ Eskandar Moghimipour, ${ }^{\mathrm{b}}$ Ali Ghorbani, ${ }^{\mathrm{c}}$ Alireza Malayeri, ${ }^{\mathrm{d}}$ Amir Siahpoosh, \\ Mahmood Khodadoost, ${ }^{\dagger}$ Mehdi Rajaeipour, ${ }^{9^{*}}$ and Kambiz Ahmadi Angali ${ }^{\text {h }}$
}

\author{
aDepartment of Persian Pharmacy, Faculty of Pharmacy, Ahvaz Jundishapur University of medical Sciences, Ahvaz, Iran. \\ ${ }^{b}$ Department of Pharmaceutics, Faculty of Pharmacy, Ahvaz Jundishapur University of medical Sciences, Ahvaz, Iran \\ cDepartment of Nephrology, Faculty of Medicine, Ahvaz Jundishapur University of medical Sciences, Ahvaz, Iran \\ dDepartment of Pharmacology, Faculty of Pharmacy, Ahvaz Jundishapur University of medical Sciences, Ahvaz, Iran. \\ eDepartment of Pharmacognosy, Faculty of Pharmacy, Ahvaz Jundishapur University of medical Sciences, Ahvaz, Iran. \\ 'School of Traditional Medicine, Shahid Beheshti University of Medical Sciences, Tehran, Iran. \\ פDepartment of Urrology, School of Medicine, Dezful University of medical Sciences, Dezful, Iran. \\ hDepartment of Biostatistics, School of Health, Ahvaz Jundishapur University of medical Sciences, Ahvaz, Iran. \\ *Correspondence to Mehdi Rajaeipour (email: Mehdirajaeipour@yahoo.com). \\ (Submitted: 09 November 2018 - Revised version received: 25 November 2018 - Accepted: 03 January 2019 - Published online: 26 February 2019)
}

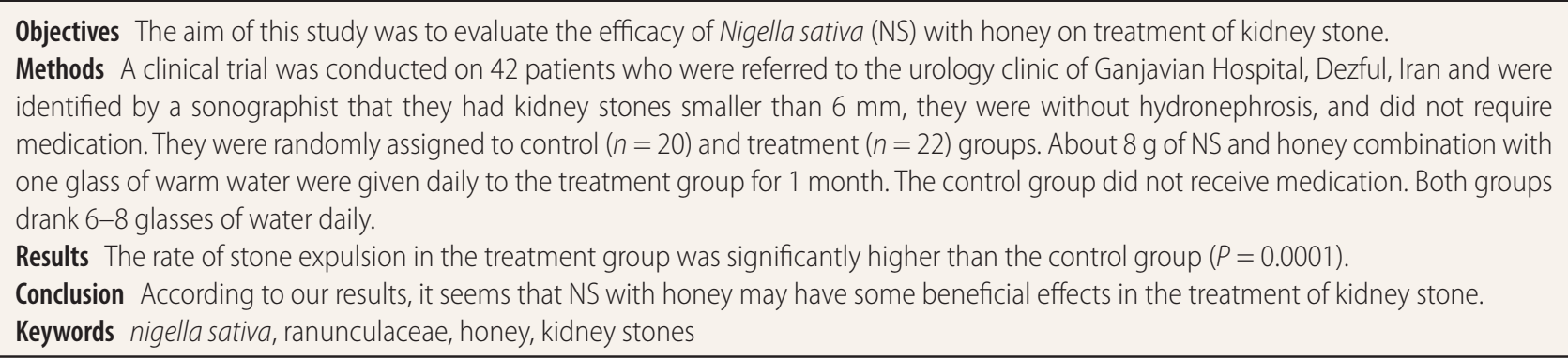

\section{Introduction}

Kidney stone is one of the most common diseases of the urinary tract, with an increasing incidence ( $6 \%$ in white women and $12 \%$ in white men).

In recent years, the occurrence of urinary stones has increased, while the age of the onset of the disease has decreased. The incidence of spontaneous recurrence after 5 years is reported between 35 and $50 \%$. In 2005, its occurrence in Iran was 147.2 per 100,000 men and 129.6 per 100,000 women and a mean recurrence rate of $16 \%$ after 1 year, $32 \%$ after 5 years, and 53\% after 10 years. In America, the cost per year for kidney stones is about $\$ 4.5$ billion. ${ }^{1-5}$

The kidney stone may cause obstruction, hydronephrosis, infection, and hemorrhage in the urinary tract. ESW, PNL, and TUL, and laparoscopy are widely used to remove stones; but the use of these invasive methods is not cost effective and causes severe complications, so replacing traditional therapies with medicinal plants or phytotherapy will be valued. ${ }^{4}$ In the traditional view, kidney stone is due to thick and sticky khilt (humor) which has lost its moisture through excessive heat over the time. ${ }^{6}$ In traditional, medicine kidney stone is treated in various ways, including body cleansing from akhlat (plural of khilt), diet, regulation of activity, sleep and wakefulness, and the use of different herbal, animal or mineral drugs, including Nigella sativa (NS) and honey. Shoniz is used in traditional medicine as a diuretic, also with warm water and honey as Mofattit (lithotriptic) of stones. ${ }^{7-9}$

In traditional medicine shoniz due to be hirrif (pungent) is used as majun (mixture) to destroy rih (wind) and heat body rapidly. ${ }^{10,11}$ Honey is also introduced as a Mofattit, diuretic and anti osr ol-bawl (difficulty in urinating). ${ }^{7}$ It is also a basis for many traditional products. It is used as a thickener, flavoring agent and vehicle in recent years. It has an antimicrobial effect due to its high viscosity too.

Several studies have been carried out on herbal products that affect urinary stones, including shoniz.

In 2007, a study evaluated effect of NS extract on prevention and treatment of calcium oxalate produced by ethylene glycol in 32 Wistar rats. Results indicated a reduced number of calcium oxalate deposits in treatment group. ${ }^{12}$ In 2008, another study examined the effect of intraperitoneal thimoquinone, the main components of NS, on 60 male Wistar rats (except for the negative control group). The stones were produced by ethylene glycol. The results showed that $5 \mathrm{mg} / \mathrm{kg}$ of thymoquinone significantly reduced the number and size of calcium oxalate deposits in the kidney tubules. ${ }^{13}$ In 1997, administration of $1 \mathrm{~g}$ of NS (as capsules), two times per day, made significant changes in blood creatinine level in healthy individual in Saudi Arabia. ${ }^{14}$

In 2016, a study on NS and its main component, thymoquinone showed positive effects in prevention or curing kidney stones and renal failure through various mechanism such as antioxidative, anti-inflammatory, anti-eicosanoid and immunomodulatory effects. ${ }^{15}$ In a study, in 2016, paracetamol administration significantly increased serum creatinine $(0.80 \mathrm{U} / \mathrm{L})$ when compared with the sham group $(0.31 \mathrm{U} / \mathrm{L})$. However, serum creatinine level was reduced to $0.64,0.57$, and $0.52 \mathrm{U} / \mathrm{L}$ with 250,500 , and $1000 \mathrm{mg} / \mathrm{kg}$ doses of the extract, respectively. Kidney histopathological examinations showed that NS antagonized paracetamol-induced kidney pathological damage. ${ }^{16}$ 
In 2016, a research showed that serum creatinine and blood urea nitrogen (BUN) in PTU group was higher than the control group. A total of $400 \mathrm{mg} / \mathrm{kg}$ of NS decreased creatinine, but both 200 and $400 \mathrm{mg} / \mathrm{kg}$ dose improved BUN concentration compared with PTU group. The results of this study demonstrate that the hydroalcoholic extract of NS has a protective effect on the renal tissue oxidative damage associated with PTU-induced hypothyroidism during neonatal and juvenile growth in rats. ${ }^{17}$ In the formation of kidney stones, biochemical factors may be changed. ${ }^{14,18}$ Yet, no comprehensive study has been accomplished on the effect of NS with honey on the stone formation and biochemical parameters of blood and urine in human.

On the other hand, this combination is used as a Mofattit in the folklore. The process is available, inexpensive and not invasive unlike existing stone breaking techniques. In the presence of honey, other excipients are not required. Therefore, the effect of a combination of NS and honey on the kidney stone was investigated in a clinical trial.

\section{Patients and Methods}

\section{Methods}

Investigation was conducted in accordance with approval protocol from Research Ethics Committee of Ahvaz Jundishapur University of Medical sciences. Code of Ethics: IR.AJUMS. REC.1396.645.

\section{Plant Material}

Nigella sativa was purchased from a local herb store in Ahvaz, Iran. The seeds were identified by the Pharmacognosy Department of Ahvaz Jundishapur University of Medical Sciences, Ahvaz, Iran. The seeds were powdered using an electric grinder and immediately mixed with honey in a proportion of 1:3. They were packed in disposable containers.

\section{Honey}

Honey from Padena Company contains $0.1 \%$ polyphenol, 520 $\mathrm{mg} / \mathrm{kg}$ prolin, $35.8 \%$ fructose, $32 \%$ glucose, and $15.2 \%$ water, while its $\mathrm{pH}$ is $5.72 .{ }^{19}$

\section{Kidney Function Study}

Calcium, phosphorus, $\mathrm{pH}$, protein, specific gravity, urine volume $24 \mathrm{~h}$, creatinine, BUN, and uric acid levels were measured by commercial assay kits (Parsazmun kit, Iran) using BT 1500 automatic analyzer. Oxalate and citrate levels were measured by commercial assay kits (Drmankav Kit, Iran) using photometer. Cistine was measured by colorimetric test.

\section{Statistical Analysis}

SPSS was used for statistical analysis. All data are presented as mean \pm SD. The data obtained were tested by independent $t$-test, Mann-Whitney, or Crosstab.

\section{Study Plan}

Total amount of polyphenol of NS was measured by FolinCiocalteu method. Antioxidant activity was evaluated by the DPPH method. Then a clinical trial was conducted on 42 patients (age $>18$ years) from 100 patients who refered to the urology clinic of Ganjavian Hospital, Dezful, Ahvaz. They did not need medication. A sonographist recognized that they had kidney stones smaller than $6 \mathrm{~mm}$, without



Fig. 1 Nigella sativa seeds and flower https://sg.carousell.com

hydronephrosis. They randomly assigned to control $(n=20)$ and treatment $(n=22)$ groups. The treatment group took $8 \mathrm{~g}$ of the combination with one glass of warm water daily for 1 month. The control group did not receive medication. Both groups drank 6-8 glasses of water per day. At the end, sonography was repeated. Blood and urine biochemical test, $24 \mathrm{~h}$ urine volume and urine $\mathrm{pH}$ and specific gravity were determined before and after intervention. The rate of stone expulsion was compared in two groups with SPSS. Exclusion criteria were pregnancy, history of the complication or sensitivity to NS, receiving drugs that affect kidney stones, use of stone breaking techniques, and diabetes.

\section{Results}

Polyphenolic content and antioxidant activity $\left(\mathrm{IC}_{50}\right)$ of NS were studied. The results were $18.53 \mathrm{mg}$ (based on tannic acid) and $0.2 \mathrm{mg} / \mathrm{ml}$ respectively. About 42 patients from 100 patients with kidney stones who referred to Ganjavian Hospital, 22 were in the treatment group and 20 in the control group; a total of 17 women and 25 men participated in the study. All participants had not cystinuria and proteinuria. There was a significant difference between age in two groups $(P=0.041)$, mean age in control group was $47.95 \pm 9.92$ and in treatment group was $56.64 \pm 12.84$. The rate of stone expulsion in the treatment group (90.9\%) was significantly higher than the control group ( $40 \%)(P=0.0001)$. The mean of stone size and stone number variables were significantly different before and after intervention in the control and treatment groups (respectively $P=0.001,0.001$ ). The mean difference of stone size in the control group was $1.25 \pm 1.55$ and in the treatment group was $3.33 \pm 0.66$. The mean difference of stone numbers in the control group was $0.4 \pm 0.5$ and in the treatment group $0.91 \pm 0.29$. The odds ratio (OR) for stone disposal in the treatment group was 15 (95\% confidence interval: $2.7-82.7)$. On the other hand, the NNT was almost equal to 2.

Comparison of uric acid in both groups before and after intervention showed significant difference $(P=0.025)$. The mean of this variable was $0.78 \pm 0.96$ in control group and 0.19 \pm 0.66 in treatment group.

The results of the comparison of serum creatinine in the control and treatment groups before and after treatment indicated that the serum creatinine difference was significant in both groups $(P=0.043)$. The mean of serum creatinine difference in the control group was $-0.015 \pm 0.13$ and in the treatment group was $0.07 \pm 0.13$. 
Other variables did not differ significantly before and after intervention in the two groups $(P>0.05)$.

Comparison of variables and their differences in both groups before and after intervention showed in (Table 1 and 2).

\section{Discussion}

This study showed that polyphenolic content and $\mathrm{IC}_{50}$ of NS were $18.53 \mathrm{mg}$ and $0.2 \mathrm{mg} / \mathrm{ml}$ respectively, indicating higher antioxidant activity of NS than Thomson and Tarocco peel and equal to Sanguinello peel.

In this study, the $\mathrm{IC}_{50}$ for NS was $0.2 \mathrm{mg} / \mathrm{ml}$. In a study, $\mathrm{IC}_{50}$ mentioned for Tarocco peel was $2.34 \mathrm{mg} / \mathrm{ml}$, for Sanguinello $0.2 \mathrm{mg} / \mathrm{ml}$, and for Thomson peel $3.46 \mathrm{mg} / \mathrm{ml}$.

The amount of polyphenolic compounds in $1 \mathrm{~g}$ of dry NS extract was $0.13 \mathrm{mg}$ for Tarocco peel, $0.19 \mathrm{mg}$ for Sanguinello peel, and $0.3 \mathrm{mg}$ for Thomson peel. ${ }^{20}$

The results of this study showed that the mean difference in the size of the stone before and after intervention in the

Table 1. Comparison of variables in both groups before and after intervention

\begin{tabular}{|c|c|c|c|}
\hline \multicolumn{2}{|c|}{ Variables } & $\begin{array}{c}\text { Mean } \pm \text { SD } \\
\text { Control }\end{array}$ & $\begin{array}{c}\text { Mean } \pm \text { SD } \\
\text { Treatment }\end{array}$ \\
\hline Age & & $47.95 \pm 9.92$ & $56.64 \pm 12.84$ \\
\hline \multirow[t]{2}{*}{ Stone size } & Before & $3.45 \pm 0.89$ & $3.39 \pm 0.65$ \\
\hline & After & $2.20 \pm 1.96$ & $0.06 \pm 0.20$ \\
\hline \multirow[t]{2}{*}{ Stone number } & Before & 1 & 1 \\
\hline & After & $0.60 \pm 0.50$ & $0.09 \pm 0.29$ \\
\hline \multirow[t]{2}{*}{ Vol. $24 \mathrm{~h}$} & Before & $1470 \pm 712.37$ & $1213.64 \pm 639.97$ \\
\hline & After & $1425.50 \pm 805.71$ & $1381.36 \pm 688.78$ \\
\hline \multirow[t]{2}{*}{ Urine Cr 24 h } & Before & $1.13 \pm 0.42$ & $1.27 \pm 0.39$ \\
\hline & After & $0.97 \pm 0.46$ & $1.09 \pm 0.34$ \\
\hline \multirow[t]{2}{*}{ Urine Ox 24 h } & Before & $16.66 \pm 13.50$ & $17.89 \pm 15.81$ \\
\hline & After & $11.24 \pm 8.53$ & $13.34 \pm 11.07$ \\
\hline \multirow[t]{2}{*}{ Urine Cit 24 h } & Before & $2.21 \pm 1.36$ & $1.98 \pm 1.48$ \\
\hline & After & $2.75 \pm 1.97$ & $2.11 \pm 1.85$ \\
\hline \multirow[t]{2}{*}{ Urine UA $24 \mathrm{~h}$} & Before & $521.68 \pm 345.85$ & $369.83 \pm 166.54$ \\
\hline & After & $573.15 \pm 405.26$ & $484.47 \pm 518.99$ \\
\hline \multirow[t]{2}{*}{ Urine Ca 24 h } & Before & $98.91 \pm 54.33$ & $162.32 \pm 99.68$ \\
\hline & After & $79.28 \pm 63.68$ & $111.15 \pm 55.29$ \\
\hline \multirow[t]{2}{*}{ Urine $\mathrm{pH}$} & Before & $5.45 \pm 0.10$ & $5.18 \pm 0.39$ \\
\hline & After & $5.20 \pm 0.62$ & $5.09 \pm 0.29$ \\
\hline \multirow{2}{*}{ Urine S. g. } & Before & $1023 \pm 8.01$ & $1024.64 \pm 7.42$ \\
\hline & After & $1026.80 \pm 4.88$ & $1025.68 \pm 6.74$ \\
\hline \multirow[t]{2}{*}{ BUN } & Before & $16.88 \pm 4.79$ & $21.15 \pm 3.38$ \\
\hline & After & $14.25 \pm 5.31$ & $17.82 \pm 5.10$ \\
\hline \multirow[t]{2}{*}{ Serum $\mathrm{Cr}$} & Before & $1.04 \pm 0.18$ & $1.10 \pm 0.20$ \\
\hline & After & $1.05 \pm 0.15$ & $1.03 \pm 0.16$ \\
\hline \multirow[t]{2}{*}{ Serum Ca } & Before & $11.08 \pm 4.31$ & $9.38 \pm 0.48$ \\
\hline & After & $9.21 \pm 0.65$ & $9.23 \pm 0.36$ \\
\hline \multirow[t]{2}{*}{ Serum P } & Before & $3.49 \pm 0.33$ & $3.46 \pm 0.34$ \\
\hline & After & $3.59 \pm 0.49$ & $3.50 \pm 0.51$ \\
\hline \multirow[t]{2}{*}{ Serum UA } & Before & $5.02 \pm 1.20$ & $5.05 \pm 1.30$ \\
\hline & After & $4.28 \pm 1.21$ & $4.73 \pm 1.26$ \\
\hline \multirow[t]{2}{*}{ GFR } & Before & $117.94 \pm 90.95$ & $104.84 \pm 77.60$ \\
\hline & After & $89.17 \pm 53.53$ & $115.20 \pm 90.70$ \\
\hline
\end{tabular}

BUN: blood urea nitrogen.
Table 2. Comparison of differences between variables before and after intervention in both groups

\begin{tabular}{|c|c|c|c|}
\hline & Variables & $\begin{array}{c}\text { Differences } \\
\text { mean } \pm \text { SD }\end{array}$ & $\begin{array}{c}P \text {-value } \\
\text { between groups }\end{array}$ \\
\hline \multirow[t]{2}{*}{ Stone size } & Control & $1.25 \pm 1.55$ & 0.0001 \\
\hline & Treatment & $3.33 \pm 0.66$ & \\
\hline \multirow{2}{*}{$\begin{array}{l}\text { Stone } \\
\text { number }\end{array}$} & Control & $0.40 \pm 0.50$ & 0.001 \\
\hline & Treatment & $0.91 \pm 0.29$ & \\
\hline \multirow[t]{2}{*}{ Vol. $24 \mathrm{~h}$} & Control & $44.5 \pm 823.26$ & 0.304 \\
\hline & Treatment & $-167.73 \pm 397.89$ & \\
\hline \multirow{2}{*}{$\begin{array}{l}\text { Urine } \mathrm{Cr} \\
24 \mathrm{~h}\end{array}$} & Control & $0.16 \pm 0.23$ & 0.848 \\
\hline & Treatment & $0.18 \pm 0.24$ & \\
\hline \multirow{2}{*}{$\begin{array}{l}\text { Urine Ox } \\
24 \mathrm{~h}\end{array}$} & Control & $5.42 \pm 13.15$ & 0.473 \\
\hline & Treatment & $4.55 \pm 13.46$ & \\
\hline \multirow{2}{*}{$\begin{array}{l}\text { Urine Cit } \\
24 \mathrm{~h}\end{array}$} & Control & $-0.54 \pm 1.26$ & 0.322 \\
\hline & Treatment & $-0.13 \pm 1.37$ & \\
\hline \multirow{2}{*}{$\begin{array}{l}\text { Urine UA } \\
24 \mathrm{~h}\end{array}$} & Control & $-51.47 \pm 496.05$ & 0.339 \\
\hline & Treatment & $-114.65 \pm 406.04$ & \\
\hline \multirow{2}{*}{$\begin{array}{l}\text { Urine Ca } \\
24 \mathrm{~h}\end{array}$} & Control & $19.63 \pm 66.45$ & 0.291 \\
\hline & Treatment & $51.17 \pm 115.37$ & \\
\hline \multirow[t]{2}{*}{ Urine $\mathrm{pH}$} & Control & $0.25 \pm 1.16$ & 0.922 \\
\hline & Treatment & $0.09 \pm 0.53$ & \\
\hline \multirow[t]{2}{*}{ Urine S. g. } & Control & $-3.8 \pm 8.04$ & 0.435 \\
\hline & Treatment & $-1.05 \pm 7.00$ & \\
\hline \multirow[t]{2}{*}{ BUN } & Control & $2.63 \pm 6.79$ & 0.689 \\
\hline & Treatment & $3.33 \pm 3.86$ & \\
\hline \multirow[t]{2}{*}{ Serum $\mathrm{Cr}$} & Control & $-0.015 \pm 0.13$ & 0.043 \\
\hline & Treatment & $0.07 \pm 0.13$ & \\
\hline \multirow[t]{2}{*}{ Serum Ca } & Control & $1.87 \pm 4.43$ & 0.677 \\
\hline & Treatment & $0.15 \pm 0.55$ & \\
\hline \multirow[t]{2}{*}{ Serum $P$} & Control & $-0.1 \pm 0.43$ & 0.689 \\
\hline & Treatment & $-0.04 \pm 0.59$ & \\
\hline \multirow[t]{2}{*}{ Serum UA } & Control & $0.78 \pm 0.96$ & 0.025 \\
\hline & Treatment & $0.19 \pm 0.66$ & \\
\hline \multirow[t]{2}{*}{ GFR } & Control & $-28.77 \pm 83.08$ & 0.087 \\
\hline & Treatment & $10.36 \pm 47.54$ & \\
\hline
\end{tabular}

BUN: blood urea nitrogen.

treatment group $(3.33 \pm 0.66)$ was more than the control group $(1.25 \pm 1.55)$. Also, the mean difference of stone number before and after intervention in the treatment group $(0.91 \pm$ $0.29)$ was more than the control group $(0.4 \pm 0.5)$. In both of them, $P$-value was equal to 0.0001 . A study found that the ethanolic extract of $N$. sativa seeds with a dose of $250 \mathrm{mg} / \mathrm{kg}$ significantly decreased the number and size of calcium oxalate deposits in different parts of Wistar rat renal tubules and also prevented damages to the tubules and calyxes. ${ }^{12}$

This study confirms the views of Aghili Khorasani, Hakim Arzani, Avicenna, and Razi. Aghili Khorasani, in Makhzan-ulAdvieh, considered honey as Jali (a medicine that serves to wipe the surface of organ cleen), monaqqi (cleansing agent), moqatti (a medicine that cuts abnormal humor off the organ without altering its consistency) of sticky balgham (phlegm) and Moisture, mofatit, diuretic and anti osr ol-bawl. He also introduced honey as a moqatti of hasah (stone), diuretic and anti osr ol-bawl.

Hakim Arzani used NS as a diuretic; also used with warm water and honey as a stone breaker in kidney and bladder. 
Avicenna, Razi, considered triturated NS with honey and warm water as an expellent of kidney stones, diuretic, qati (cutter) of digestive thick akhlat. ${ }^{7-9,11,21}$ The rate of expulsion in the treatment group (90.9\%) was significantly higher than the control group $(40 \%)$, which indicated a potent stone removal effect of the combination $(P=0.0001)$.

In the formation of kidney stone, $24 \mathrm{~h}$ urine volume and blood or urine biochemical factors such as phosphorus, calcium, citrate, uric acid, oxalate, etc. may be changed. ${ }^{14,18}$

Serum uric acid decreased in both groups after the intervention, but its decrease in the treatment group $(0.19 \pm 0.66)$ was significantly lower than the control group $(0.78 \pm 0.96)$ $(P=0.025)$

A study in 1997 found that taking $1 \mathrm{~g}$ of NS, two times a day, in healthy subjects, resulted in no significant changes in serum uric acid levels. ${ }^{14}$

Serum creatinine increased in the control group and decreased in the treatment group. The mean of serum creatinine differences in the control group was $-0.015 \pm 0.127$ and in the treatment group was $0.07 \pm 0.13$. Mean serum creatinine before and after treatment in two groups had a significant difference $(P$ $=0.043)$. A study on rats in 2017 , found that the serum creatinine was reduced by dose of $400 \mathrm{mg} / \mathrm{kg}$ of NS extract. ${ }^{17}$ In another study (2016), serum creatinine levels were associated with a significant decrease following the use of $5 \mathrm{mg} / \mathrm{kg}$ of NS oil for 28 days in Wistar rats $(P<0.01) .{ }^{22} \mathrm{~A}$ research $(2016)$ showed that the administration of paracetamol significantly increased the serum creatinine level $(0.80 \mathrm{U} / \mathrm{L})$ compared with the sham group $(0.31 \mathrm{U} / \mathrm{L})$; the serum creatinine level was reduced to $0.64,0.57$, and $0.52 \mathrm{U} / \mathrm{L}$ with 250,500 , and $1000 \mathrm{mg} / \mathrm{kg}$ doses of NS extract, respectively. ${ }^{16}$ A study in Saudi Arabia, indicated that administration of $2 \mathrm{~g}$ /day of NS, made significant changes in blood creatinine level in healthy individuals. ${ }^{14}$

There were no complications following the use of combination during the study. It can be concluded that there is no renal damage due to treatment with the combination. It confirms the nephroprotectrivy of the combination. A clinical study (2010) found that NS at doses of 1-3 g/day for 3 months did not adversely affect renal and hepatic functions of diabetic patients. ${ }^{23}$

\section{Conclusion}

According to the odds ratio $(\mathrm{OR}>10)$, stone expulsion in the treatment group is 15 times more than the control group. Therefore, there is a meaningful relationship between the stone expulsion and intervention type. On the other hand, the NNT is almost equal to 2; that is, clinically in the community, one person is treated from two people who receive the combination. Also, a significant reduction in the stone number and size in the treatment group may be indicated to crush or dissolve the stones by the combination, which approves traditional use of NS majun in kidney sone. The mechanism of action is probably antioxidant and stone breaker.

\section{Acknowledgment}

This research was supported by Ahvaz Jundishapur University of Medical Sciences, Ahvaz, Iran (Grant No. MPRC - 9613).

\section{Conflict of Interest}

None.

\section{References}

1. Moe OW. Kidney stones: pathophysiology and medical management. Lancet. 2006;367:333-344.

2. Tiselius HG. Epidemiology and medical management of stone disease. BJU Int. 2003;91:758-767.

3. Devuyst O, Pirson Y. Genetics of hypercalciuric stone forming diseases. Kidney Int. 2007;72:1065-1072.

4. Fink HA, Wilt TJ, Eidman KE, Garimella PS, MacDonald R, Rutks IR, et al. Medical management to prevent recurrent nephrolithiasis in adults: a systematic review for an American College of Physicians Clinical Guideline. Ann Intern Med. 2013;158:535-543.

5. Safarinejad MR. Adult urolithiasis in a population-based study in Iran: prevalence, incidence, and associated risk factors. Urol Res. 2007;35:73-82.

6. Shah Arzani MA. Mizanoteb. Researcher: Nasiri H, Qom: Sama Cultural Institute.1380 SH.159-160.

7. Aghili Shirazi MH. Makhzan Al-Advia. Ahmed Kabir et al. (Eds.). Hindustan, 1260;557.

8. Shah Arzani MA. Akbari Medicine. 1 15t Ed.; Qom, Jalaluddin, Vol. 2, 2008;825-845

9. Ibn Sina H. The Canon of Medicine. $1^{\text {st }}$ Ed.; Beirut, Arabic Scientific Foundation, Vol. 2, 1426 AH; p. 139

10. Razi MZ. Taghsim al-ellal. Sobhi Mahmud H. (Ed.). Aleppo, Arab Scientific Foundation, $1412 \mathrm{AH} ; 755$

11. Ibn Sina H. The Treatise on Colic (Qulanj) by Avicenna. Sobhi Mahmud H. (Ed.) Aleppo, Arabic Scientific Foundation, 1403 AH;220.

12. Khoei $A$, Hadjzadeh Z, Parizady M. Ethanolic extract of Nigella sativa $L$ seeds on ethylene glycol-induced kidney calculi in rats. Urol J. 2009:4:86-90.

13. Hadjzadeh MA, Mohammadian N, Rahmani Z, Rassouli FB. Effect of thymoquinone on ethylene glycol-induced kidney calculi in rats. Urol J. 2008:5:149-155
14. Bamosa AO, Basil A, Sowayan AA, Sowayan SA. Effect of oral ingestion Nigella sativa seeds on some blood parameters. Saudi Pharma J. 1997:5:126-129.

15. Hayatdavoudi P, Khajavi Rad A, Rajaei Z, Hadjzadeh MA. Renal injury, nephrolithiasis and Nigella sativa: a mini review. Avicenna J Phytomed. 2016;6:1-8.

16. Canayakin D, Bayir Y, Kilic Baygutalp N, Sezen Karaoglan E, Atmaca HT, Kocak Ozgeris FB, et al. Paracetamol-induced nephrotoxicity and oxidative stress in rats: the protective role of Nigella sativa. Pharm Biol. 2016;54:2082-2091.

17. Mohebbati R, Hosseini M, Haghshenas M, Nazariborun A, Beheshti F. The eff ects of Nigella Sativa extract on renal tissue oxidative damage during neonatal and juvenile growth in propylthiouracil-induced hypothyroid rats. Endocr Regul. 2017;51:105-113.

18. Ghorbani A, Shahbazian H, Moradi L. Risk factors of renal stone in patients with recurrent nephrolithiasis: a case-control study. Life Sci J. 2012;9:3038-3043.

19. Institute of Standards and Industrial Research of IRAN. Honey: Specifications and test methods. 7th revision. 2013; Number 92.

20. Fatahi Moghadam J, HY, Fotohi Ghazvini R, Ghasem Nejad M, Bakhshi D. Evaluation of physicochemical and antioxidant properties of some commercial citrus varieties. J Hortic Sci. 2011;25:211-217.

21. Razi MZ. The Book of Colic (Qulanj). Sobhi Mahmud H (Ed.). Aleppo, University of Aleppo, Arabic Scientific Foundation, 1403 AD; p. 122.

22. Benhelima A, Kaid-Omar Z, Hemida H, Benmahdi T, Addou A Nephroprotective and diuretic effect of Nigella sativa $L$ seeds oil on lithiasic wistar rats. Afr J Tradit Complement Altern Med. 2016;13:204-214.

23. Bamosa AO, Kaatabi H, Lebdaa FM, Elq A, Al-Sultanb A. Effect of Nigella sativa seeds on the glycemic control of patients with type 2 diabetes mellitus. Indian J Physiol Pharmacol. 2010;54:344-354. 